\title{
The Meta-Analysis of Climate Resilience Education in Higher Education for Transformation Based on Experiential Learning Models
}

\author{
Dwiyono Hari UTOMO 1 \\ Universitas Negeri Malang, INDONESIA
}

\author{
Muhammad ALIMAN 2 \\ Universitas Negeri Malang, INDONESIA
}

\begin{abstract}
1 Corresponding author: Assoc. Prof. Dr. Universitas Negeri Malang, Faculty of Social Science, Department of Geography Education, INDONESIA. E-mail: dwiyono.hari.fis [at] um.ac.id. ORCID: 0000-0002-4205-1063

2 Dr. Universitas Negeri Malang, Faculty of Social Science, Department of Geography Education, INDONESIA. E-mail: muhammad.aliman.1607219 [at] students.um.ac.id. ORCID: 0000-0001-9918-3991
\end{abstract}

\begin{abstract}
The geographical and astronomical position of the Indonesian archipelago causes Indonesia to have two seasons, namely the rainy and dry seasons. The rainy season occurs in October-March, and the dry season occurs in MarchOctober. The rainy season often occurs with high rain intensity, especially during the La-Nina period, on the other hand, the dry season often occurs with low rain intensity, especially during the EFNino period. The effects of both can be seasonal disasters that threaten human life. The purpose of this research is to explore the idea of climate resilience education in higher education in order for it to be transferred to the public. The research method used metaanalysis through the overlay concept to find ideas on climate resilience education. The results found ideas that were then grouped into methods, contents, and actions of students aligned with learning objectives. Climate resilience education can be included in climatology or hydrometeorology courses based on experiential learning models. Activities carried out in climate resilience education aim encouraging a caring attitude for the environment and become the basis for transformation in society.
\end{abstract}

\section{Keywords}

Indonesia, Meta-Analysis, Transformation, Climate Resilience Education

To cite this article: Utomo, H. D.; Aliman, M. (2021). The meta-analysis of climate resilience education in higher education for transformation based on experiential learning models. Review of International Geographical Education (RIGEO), 11(2), 302-316. doi: 10.33403rigeo.754200 
Climate change disrupts the seasonal cycle in Indonesia, where there are high and low extreme rains that become hydro meteorological disasters. As of April 10, 2020, there were 1,069 total disasters of which 388 cases were dominated by hydro meteorological disasters. This disaster caused damage to housing, infrastructure, and other public facilities. The total number of damaged houses with different levels was more than 16 thousand, with details of heavy damage to 3,554 units, moderate damage to 2,489 units, and minor damage to 10,331 (Ariansyah, 2020). According to the BNPB Report (2013), hydro meteorological disasters reached 137 out of 144 disasters in Indonesia in July-August 2013 (Gengaje \& Farquhar, 2013). West Sumatra on the south coast experiences floods and landslides caused by rain $>125$ $\mathrm{mm}$ / day, the denotational hilly areas and open land (LAPAN, 2007). Spatial distribution of locations is vulnerable to climate change and results in flooding which occurs in sloping coastal areas and areas close to river deltas, mountains, and poorly drained terrain

Heavy rain with high intensity is a major factor in hydro meteorological disasters such as floods. Floods that occur in Indonesia are generally caused by the overflowing river when it rains heavily (Bloomer, Landeg, \& le Polain de Waroux, 2019). The flood occurred on the left-right side of the river and was temporary. Elsewhere, the flood could occur in the basin topography or lower areas, so it waterlogged even though it is far from the river. Flooding can also occur in urban areas due to clogged sewers or drainages during heavy rains. The cause of the flood can be identified, and the solution can be determined. Various areas affected by floods have made arrangements and improvements, such as building dams, building infiltration wells, pumping stagnant water, deepening river basins, making river banks, and mitigating flood disasters (Katko, Jutti \& Harjono, 2010). It can recur in the same area at different times which then referred to as a "flood plain" area. Frequent flooding can disturb the activities of the community.

Human actions could trigger floods and even worsen their impact (Bloomer et al., 2019; Viero. Roder, Matticchio, Defina, \& Tarolli, 2019). The choices made by humans did not support the environment, such as illegal logging in upstream areas, littering, building houses along riverbanks, building housing complexes without sufficient drainage, or using drainages from concrete. Such conditions not only reduced absorption but also instead increased surface flow which turned to a flood. Anthropogenic factors regarding human activities provided opportunities for various educational institutions to conduct socialization, and counseling.

Education as a critical determinant of transformation human habits (Luetz, Margus, \& Pricket, 2020). Changing bad habits such as throwing rubbish in the river, in the gutter, and at random places can be educated and trained. The changes can be done for example by planting and caring for trees, making infiltration wells, making bio pores, making terraces, making embankments, providing garbage bins, cleaning the environment, and environmentally responsive (Mashur \& Meiwanda, 2019). These changes could occur if given education, specifically climate resilience education. Therefore climate resilience education is focused on changing behavior and actions (Krasny \& Chaopricha, 2015). 
The climate changes from normal to extreme, normal rain also change to abnormal rain (above or below normal). Rainfall above normal causes flooding, while below normal causes drought. They both have an impact on people's lives. Climate change developed thinking to save and prevent or reduced socio- economic impacts (Tong \& Ebi, 2019). Such thinking creates the process of adaptation that furthers climate resilience. Adaptation is an actual climate adjustment to avoid danger. Resilience as the capacity of social systems to deal with dangerous events, responds to, or rearranges the system. Climate adaptation and resilience need others to conduct literacy and education about climate change and its impacts by facilitating it through climate resilience education (Nayan, Mohamedisa, Hanifah, Yazid, \& Syaldatna-Balkis, 2020; Schrot, Keller, Peduzzi, Reide, Kuthe, \& Lidwig, 2019).

\section{Climate Education}

Climate education in America part of Environmental Education, which is managed by the US Environmental Protection Agency. Environmental Education aims at making people care and focus on the environment which is a social problem, as well as having the knowledge, skills, attitudes, motivation and commitment to work individually and collectively leading to solutions for current problems and how to prevent them (Krasny \& Chaopricha, 2015). Effective themes in climate change education include: engaging in deliberative discussions, interacting with scientists, addressing misconceptions, implementing school and community projects (Alberta Council for Environmental Education, 2017).

In chapter 2 article 3 of the Qanun in Aceh about Disaster Education, it was written that the function of disaster education was to develop all aspects of the learner's personality in order to create an Acehnese society that is responsive and alert to disasters (Qanun is local regulation used specifically in Aceh region, Indonesia). Furthermore, in article 4 it is written that the purpose of disaster education is to develop all the potential of students to become human beings who: a) believe in and fear of God, b) have good character, c) have knowledge of disaster, d) have an attitude and concern for disaster risk, e) disaster response and preparedness, and f) have the ability to adapt to big and sudden changes. Disaster education held on formal, informal and non-formal education. Formal education range from early childhood education to college (DPR Aceh and Gubernur, 2019).

Climate resilience education in college institutions intended to be a transformer in society, so that students and the community could have a disaster response attitude, have the ability to adapt to major changes and can educate through nonformal and informal courses for care and concern about the environment which is a social problem, and have knowledge, skills, attitudes, motivation and commitment to work individually and collectively towards solutions (Schrot et al., 2019). Previous studies showed that the ability of students and pre-service teachers or early-career teachers to understand climate change was low (Bozkurt, 2019; Chang \& Pascua, 2015; Lane, 2015; Nayan et al., 2020; Piróg, 2014; Seroussi, Rothschild, 
Kirzbaum, Yaffe \& Hemo, 2019). Therefore, it is necessary to design climate resilience education that can easily transfer to students and the community.

\section{Theoretical Framework}

\section{The Effect of Climate Change}

Flooding is a natural phenomenon caused by overflow. Overflow is a response to the excess of water supply that cannot be accommodated by rivers or water infiltration. The water sources come from rainfall or hydro meteorological events. It is stored in the atmosphere as clouds and occurs as a result of the condensation of water vapor from evapotranspiration poured out on the surface of land and sea. There are various amounts and sizes of rains. The amount is influenced by the duration and scope of cloud cover in the region. The amount of rain is expressed in millimeters for a specific duration of time or called a thick rain. At the thickness of the rain and the measured area, it can be known the volume of rain. This volume has an impact on a puddle or flood that cannot be accommodated by water infiltration.

Due to sloping topography and downstream of the river, flooding can come from the upstream area and the sea (rob/tidal flooding, tides inundating the land). The sea as a river delta was affected by tides. At high tide, the river water is unable to flow into the sea because the sea level rises, resulting in flood and permanently forming swamps. At low tide, the river water flows into the sea, so there is no flood on land. This tidal rhythm is very influential in the area near the estuary. Otherwise, it can cause salty water to expand in the delta area. At low tide, the farming community can do rice farming (Nhan, Be, \& Trung, 2007).

Rain in Indonesia does not only occur in the rainy season but also in the dry season because of the influence from La-Nina. The La Niña and Southern Oscillation phenomena can cause catastrophic floods. The phenomenon is the dynamics of Walker's circulation which is supported by global warming so that changes in rainfall intensity occur during ENSO (Kurniawan, 2009). Due to the position of Indonesia crossed by ITCZ, the conversion can result in heavy rains or torrential rains. Rain occurs from cumulus clouds that turn into cumulonimbus clouds which produce heavy rain (shower), so it is called extreme weather or "wild weather" (Kasih, Juaeni, \& Harijono, 2007).

ENSO (El-Nino-Southern Oscillation) is one of the factors that influence climate in Indonesia every few years, which triggers various extreme weather events. ElNino was related to changes in ocean tides in the South Pacific that have caused drought in Indonesian, due to rain in the South Pacific Sea. Meanwhile, when the tide becomes very cold, called La Nina, Indonesian experiences heavy rain. From 18442006, out of 43 long dry seasons, 37 times were related to El Nino (UNDP Indonesia, 2007).

Heavy rain is generally rain that is above the normal limit. Heavy rain that is not balanced with good drainage will cause inundation because the downward flow runs slowly, causing the flow to the surface to rise quickly. Surface flow velocity 
produces flow strength resulting in erosion and landslides. Landslides not only occur because of rain but accelerated by the hilly and mountainous topography that has a large slope angle. Heavy rain on the topography in a basin will make a puddle because the land surface is lower than the drain or river. In urban areas, the flood is more frequent because the absorption capacity is smaller than the flow rate. It happens because the city area is closed to buildings and drainage is unable to accommodate it. Excess water that flows on the surface become floods then goes into rivers that eventually reach the estuary, then this rainwater is wasted more and brings disaster so that it becomes useless of its utilization. Rainwater should be a blessing, but it is wasted due to flooding and becoming a disaster, while in other areas where there is no rain, drought is also unfortunate.

Floods and landslides are interrelated events. Heavy rains triggered by steep slopes cause landslides. In steep slopes, the soil is unable to be held between particles due to gravity. Porous soils allow rainwater to pass through the pores of macro or micro soils. The vertical movement of the water down stops when it encounters an impermeable layer so that the water moves above to form a slip plane. The skidding area enriched with clay causes the mass movement to hurry, causing landslides. Landslides can occur in the river courses which erode the riverbanks. Floods can erode and damage residential areas cause's landslides and wash away houses, animals, rice fields, farms, and even humans.

\section{Climate Resilience Education}

Climate resilience education contains the teaching materials which is mostly a science concept. The phenomenon of climate change in various regions occurs due to physical processes, such as atmospheric dynamics, changes in the appearance of steam to water or ice. Students in social sciences are certainly not interested because they do not understand. Therefore, climate resilience education will accommodate from various fields of science or simplify the concepts of physics that can be recognized in student life. Climate resilience education incorporates more social science and behavioral principles in the climate science equation, and offers students the opportunity to identify possible interventions that can have direct and long-lasting impacts (Bey \& Allen, 2019). Thus climate resilience education is directed at increasing adaptation capacity (Below, Artner, Siebert, \& Sieber, 2010) through understanding, changing habits, and developing practical skills on climate change and its impacts (Reid, 2019).

Activities that involve students are actively discussing their understanding and practicing actions with concepts, and engaging with relevant local examples of the impacts of climate change through methods of field visits and data collection (Monroe, Plate, Oxarart, Bowers, \& Chavez, 2019). Climate change has a serious impact on the most vulnerable areas such as coastal areas due to strong winds and tidal floods, and mountainous areas due to landslides, and areas that are sloping lower than rivers. Understanding of vulnerable areas can be done through analysis of geographic information systems (GIS) which results in the mapping of hydro meteorological vulnerable areas. Community's understanding about climate change 
is also very important in order to build sustainable communication on climate resilience (Paytan, Weiss \& Halversen, 2017).

The transformation of climate resilience education aims at communities who have been exposed to climate disasters. They are shown to a large number of human victims, loss of jobs, polluted ecosystems, damaged infrastructure, socio-economic decline, and loss of cultural assets (Miola, Paccagnan, \& Mandrici, 2015). The transformation of climate resilience education to the community is carried out using learning by doing or experiential learning methods that involve the community in an activity together (Sumarmi, Bachri, Irawan, Putra, Risnani \& Aliman, 2020). Explanation of the concept is more directed to the pragmatic and contextual concepts that occur in the community using guidance and counselling methods through physical and visual demonstration accompanied by workshops. The physical and visual demonstration was done on how to use tools and their applications to objects (learning by doing). The community saw it directly and participated in doing it and implementing it. The orientation of application to the family environment, such as make bio pores, plant trees or others as a barrier and shield, can also be an ornamental plant. In certain areas, each family can plant trees in the yard or on the terrace of the house so that the community can build a green village that is significant and can control and ameliorate the microclimate (Andrade \& Vieira, 2007; Georgi \& Zafiriadis, 2006).

\section{Methodology}

\section{Research Design}

This research used meta-analysis as a study of various data sources by finding elements of education that can be used and contained content related to climate resilience education. The purpose of education as a learning outcome was based on the four pillars of 21st-century education, which are learning to know, learning to do, learning to live together in peace, and learning to be. It contains critical thinking skills and problem-solving, communication, creativity and innovation, agility and adaptability, collaboration and leadership, initiative and spirit of an entrepreneur, able to access and analyze information, have curiosity and imagination (Bozkurt, 2019; Direktorat Pembinaan Sekolah Menengah Atas (Directorate of High School Development), 2017; Zubaidah, 2016). Furthermore, the objectives of climate resilience education are adjusted to the standards of learning outcomes in meteorology-climatology or hydrometeorology courses.

\section{Data Collection}

The data comes from books, journals, and news that are collected and sorted according to climate resilience topics. The sorting is based on the meta-analysis work diagram. The working diagram of the meta-analysis can be seen in Figure 1. Education of climate resilience objectively studies climate and climate change in the world and Indonesia as a function of 'learning to know'. Education is interpreted as a conscious effort to shape, change, or improve behavior and actions as a function of 'learning to do' and 'learning to be'. Disaster impacts of climate change can be directly felt due to extreme weather that affects people's lives. Disasters that often 
occur can be learning to strengthen, survive, and struggle to find solutions. Integration of the concepts of education, climate change and the impacts of climate change is described. Then a systematic review is carried out, which is doing synthesis and filtering based on standards of learning outcomes. Finally, a metaanalysis is carried out as alignments based on the objectives of climate resilience education and make the content in resilience education climate.
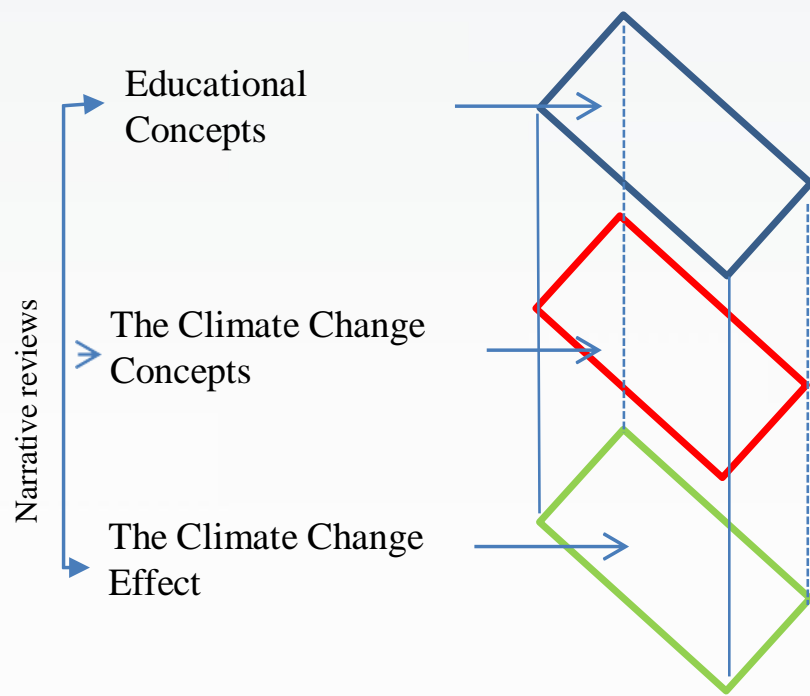

Systematic Reviews

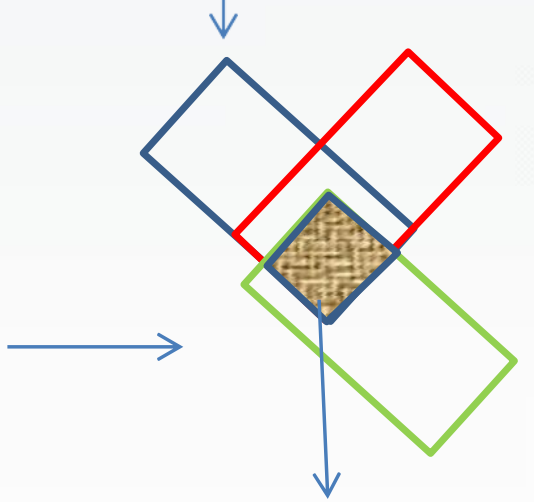

Climate Resilience Education

(Meta-Analysis)

Figure 1. The Meta-Analysis of Climate Resilience Education

\section{Data Analysis}

Text data cannot be analyzed using inferential statistics but can be analyzed using meta-analysis. Meta-analysis is a statistical analysis that combines or integrates the results of several independent clinical trials considered by the analyst to be combinable (Huque, 1988 in Gogtay \& Thatte, 2017). Meta-analysis is done through filtering processes, collecting selected library sources, conducting reviews, interpretations, sorting and classification, synthesis, alignment, and conclusion. The final result is a logical framework of climate resilience education in Indonesian college institutions.

Analysis of the climate resilience education objectives refers to the life-based curriculum, namely SCPL (standards for graduate learning outcomes) and CPMK (subjects' learning outcomes). SCPL that has been designed was able to analyze environmental phenomena and disasters through regional, social, economic surveys using geospatial technology with logical, critical, systematic, innovative and responsible thinking. Learning outcomes will be achieved by students so they are able to respond positively to the impacts of climate change (floods and drought) as a result of logical, critical, systematic and innovative thinking so as to prevent, reduce impacts and even become resistant to climate change.

Content analysis based on standard-based content has adjusted to CPMK and developed based on relevant literature sources (Bozkurt, 2019). Analysis of learning 
Utomo, H. D.; Aliman, M. (2021). The meta-analysis of climate resilience education in higher...

methods based on SCPL was a survey using geospatial technology and other methods that support, such as workshops, demonstrations, and learning by doing using problem-based learning, project-based learning (Zubaidah, 2016), experiential learning (Sumarmi et al., 2020), and outdoor study models. Learning media analysis was based on the needs of students and the community, such as real media and audio-visual that can accelerate the process of presentation and acceptance in the minds of students and society.

\section{Literature Studies}

Some selected sources of literature in Table 1 can be found from the educational element after going through a process of review and analysis that contains the educational element.

Table 1

Analysis of Educational Elements in the Literature

\begin{tabular}{|c|c|c|}
\hline No & Literature Sources & Educational Elements \\
\hline 1. & $\begin{array}{l}\text { Alberta Council for } \\
\text { Environmental Education, } \\
\text { (2017) }\end{array}$ & $\begin{array}{l}\text { Engaging in deliberative discussions, interacting } \\
\text { with scientists, addressing misconceptions, } \\
\text { implementing school and community projects }\end{array}$ \\
\hline 2. & $\begin{array}{l}\text { Below, Artner, Siebert, \& } \\
\text { Sieber, (2010) }\end{array}$ & Increase adaptation capacity \\
\hline 3. & Boer \& Kartikasari, (2007) & To build the ability to adapt to climate risk \\
\hline 4. & $\begin{array}{l}\text { Bush, Sieber, Chandler, \& } \\
\text { Sohl, (2019) }\end{array}$ & The climate education based on technology \\
\hline 5. & $\begin{array}{l}\text { DPR Aceh and Gubernur } \\
\text { (People's Representative } \\
\text { Council of Aceh and } \\
\text { Governor), (2019) }\end{array}$ & $\begin{array}{l}\text { The function of disaster education is to develop all } \\
\text { aspects of students' personalities in order to realize } \\
\text { the Acehnese society that is responsive and alert to } \\
\text { disasters. }\end{array}$ \\
\hline 6. & $\begin{array}{l}\text { International Labour } \\
\text { Organization (ILO, n.d.) }\end{array}$ & $\begin{array}{l}\text { Green Job: Reducing consumption of energy and } \\
\text { raw natural resources; limit greenhouse gas } \\
\text { emissions; minimize waste and pollution; } \\
\text { Protect and improve ecosystems. }\end{array}$ \\
\hline 7. & $\begin{array}{l}\text { Miola, Paccagnan, \& Mandrici, } \\
\text { (2015) }\end{array}$ & Climate resilient development \\
\hline 8. & Prayoga \& Sutarto, (2018) & $\begin{array}{l}\text { Understanding the city's existing conditions on the } \\
\text { risks of climate change and their impact on city } \\
\text { development. }\end{array}$ \\
\hline 9. & $\begin{array}{l}\text { Puspijak dan BPTK } \\
\text { Pengelolaan DAS Solo } \\
\text { (Climate Change Research and } \\
\text { Policy Center and } \\
\text { Conservation Technology } \\
\text { Research Center on } \\
\text { Watershed management in } \\
\text { Solo), (2013) }\end{array}$ & $\begin{array}{l}\text { Make the community resilient and able to adapt to } \\
\text { changing environmental conditions }\end{array}$ \\
\hline 10. & Qodriyatun, (2013) & Improvement of environmental quality \\
\hline 11. & Taylor, (2013) & $\begin{array}{l}\text { Raise awareness and build organizational } \\
\text { Capacity to respond to disasters and climate change }\end{array}$ \\
\hline
\end{tabular}




\begin{tabular}{cll}
\hline \hline No & \multicolumn{1}{c}{ Literature Sources } & \multicolumn{1}{c}{ Educational Elements } \\
\hline 12. & $\begin{array}{l}\text { The World Bank Groups, } \\
(2019)\end{array}$ & $\begin{array}{l}\text { Developing the next generation of climate change } \\
\text { risk assessment methodologies for high-risk } \\
\text { sectors }\end{array}$ \\
\hline 13. & $\begin{array}{l}\text { Undang-Undang Republik } \\
\text { Indonesia Nomor 16 (The } \\
\text { Law of the Republic of } \\
\text { Indonesia Number 16), } \\
(2016)\end{array}$ & $\begin{array}{l}\text { Enhancing the ability to adapt to the negative } \\
\text { impacts of climate change, towards climate } \\
\text { resilience and low emissions development, }\end{array}$ \\
Without threatening food production.
\end{tabular}

\section{Findings}

\section{Classification on Literature}

Literature studies that have interpreted are seen in Table 2. As a result of sorting and classification, the classification is divided based on the content, method, objectives, and actions interpreted.

Table 2

Classification of Literature into Content, Methods, Goals, Actions, and Interpretations

\begin{tabular}{|c|c|c|}
\hline No & Literature & Interpretation \\
\hline 1. & Content & \\
\hline & $\begin{array}{l}\text { Understanding of the city's conditions } \\
\text { related to the risks of climate change and } \\
\text { their impact on city development; Waste and } \\
\text { pollution; Natural resources, ecosystem } \\
\text { improvement, and greenhouse gas emissions } \\
\text { (Prayoga \& Sutarto, 2018; International } \\
\text { Labour Organization (ILO, n.d.) }\end{array}$ & $\begin{array}{l}\text { Global climate change, } \\
\text { Greenhouse effect, Global } \\
\text { warming, Indonesian climate, } \\
\text { impacts of climate change (floods, } \\
\text { drought, warming temperatures, } \\
\text { tornadoes), Understanding of } \\
\text { spatial conditions of the region } \\
\text { against the risks of climate change, } \\
\text { Development of climate resilience, } \\
\text { adaptation, resilience, and } \\
\text { mitigation. }\end{array}$ \\
\hline
\end{tabular}

\section{Purpose}

Raising awareness and developing organizational capacity to respond to disasters and climate change; Developing adaptability to climate risks and increasing adaptability towards the negative impacts of climate change such as climate resilience and low emissions development without threatening food production; Making communities resilient and able to adapt to the conditions of a changing environment; Developing all aspects of learners' personalities in order to create a Acehnese
Increasing student awareness and building response capacity for climate change, increasing the ability to adapt to the impacts of climate change, increasing responsiveness and alertness to climate resilience that can be transformed to the public. 
Utomo, H. D.; Aliman, M. (2021). The meta-analysis of climate resilience education in higher...

\begin{tabular}{|c|c|c|}
\hline \multirow[t]{2}{*}{ No } & Literature & Interpretation \\
\hline & $\begin{array}{l}\text { society that is responsive and alert to } \\
\text { disasters; Increasing climate change } \\
\text { education in affected / vulnerable } \\
\text { communities; Reducing the impact of } \\
\text { disasters, and accustoming people to be } \\
\text { responsive and alert to disasters that occur } \\
\text { (Below et al., 2010; Boer \& Kartikasari, 2007; } \\
\text { DPR Aceh and Gubernur (People's } \\
\text { Representative Council of Aceh and } \\
\text { Governor), 2019; Puspijak dan BPTK } \\
\text { Pengelolaan DAS Solo (Climate Change } \\
\text { Research and Policy Center and Conservation } \\
\text { Technology Research Center on Watershed } \\
\text { management in Solo), 2013; Taylor, 2013; } \\
\text { The World Bank Groups, 2019; Undang- } \\
\text { Undang Republik Indonesia Nomor 16 (The } \\
\text { Law of the Republic of Indonesia Number } \\
\text { 16), 2016; UNESCO, 2012). }\end{array}$ & \\
\hline 3. & $\begin{array}{l}\text { Method } \\
\text { Discussion and consultation; Interaction } \\
\text { with scientists, communal projects and } \\
\text { climate education based on technology; } \\
\text { Integrate climate change responses into } \\
\text { education in schools; Develop climate change } \\
\text { risk assessments (Alberta Council for } \\
\text { Environmental Education, 2017; Bush, } \\
\text { Sieber, Chandler, \& Sohl, 2019; Taylor, 2013; } \\
\text { UNESCO, 2012). }\end{array}$ & $\begin{array}{l}\text { Discussion, expert use, Project- } \\
\text { Based Learning (PBL), Using } \\
\text { technology media, outdoor study, } \\
\text { mapping of disaster-prone areas } \\
\text { through GIS applications. }\end{array}$ \\
\hline \multirow[t]{2}{*}{4.} & Action & \\
\hline & $\begin{array}{l}\text { Reducing consumption of energy and raw } \\
\text { natural resources; Limiting greenhouse } \\
\text { gas emissions; Minimizing waste and } \\
\text { pollution; Protecting and improving } \\
\text { ecosystems; Conducting climate change } \\
\text { education in affected / vulnerable } \\
\text { communities (International Labour } \\
\text { Organization (ILO), n.d.; Puspijak dan } \\
\text { BPTK Pengelolaan DAS Solo (Climate } \\
\text { Change Research and Policy Center and } \\
\text { Conservation Technology Research Center } \\
\text { on Watershed management in Solo), 2013; } \\
\text { Qodriyatun, 2013). }\end{array}$ & $\begin{array}{l}\text { Conduct formal education in } \\
\text { college institutions, and non- } \\
\text { formal education in the } \\
\text { community about climate } \\
\text { change and its impacts so that } \\
\text { students and their communities } \\
\text { can adapt and mitigate climate } \\
\text { change in their regions, make } \\
\text { infiltration wells, bio pores and } \\
\text { rain harvesting. }\end{array}$ \\
\hline
\end{tabular}

\section{Result and Discussion}

Climate resilience education is an effort to prepare, anticipate and strengthen student responses to climate change and its impact on people's lives so that people can have a strong and directed "resilience" of personal and communal adaptation 
and mitigation (Nayan et al., 2020). The appropriate learning model is applied to students, especially in areas affected by climate change (floods, landslides, droughts, tornadoes) using experiential learning by presenting hydro meteorological disaster experts and utilizing GIS for mapping disaster-prone areas. Climate resilience education materials include global climate change, the greenhouse effect, global warming, the climate of the Indonesian region, the impact of climate change (floods, drought, global warming, and tornadoes), understanding of the spatial conditions of the region against the risks of climate change, and the development of climate resilience, adaptation, resilience, and climate disaster mitigation. The learning media used are real media that can be seen and touched or audio-visual media.

Climate resilience education is directed towards changing attitudes to care about the environment due to climate change and pranoto mongso as an anthropogenic phenomenon (National Coordinating Agency for Spatial Planning, 2011) (pronoto mongso is a Javanese term that is used to calculate weather forecasts). Humans act as a 'man-made climate' so that the focus of changing attitudes on society should be enforced. Community activities that cause climate change and have an impact on other communities and even on the world community have started from the narrow surrounding environment. Chronologically a phenomenon of climate change can determine the role of the community in climate change, for example, Jakarta. Spatially the Jakarta area is a region near the coast with warm and hot temperatures. It is a consequence of areas near the coast, such as Surabaya or along the north coast of Java (also known as Pantura). Areas far from the coast should be colder, especially in the mountains. However, if the area is far from the coast and the temperature is hot, then community activities are questioned as to whether community activities have contributed heat to the environment. If the answer is yes, then in Jakarta it will certainly be much hotter because the activities of the community contribute heat to the environment. Because the distance from the coast cannot be controlled, anthropogenic factors are the primary key in controlling climate change.

Changes in community attitudes start from the environment itself as individuals or as families, for example making bio pores in the home yard, making infiltration wells, making drainage canals, planting trees or ornamental plants, cooking not using firewood, not using spray paint and hairspray that contain harmful freon. Many slogans have been put forward to protect or reduce the impact of climate change, such as' one man one tree ',' greening my earth ',' ijo royo-royo (green rainbow)', green roof' aimed at oxygen production. Local wisdom can slow the rate of climate change (especially microclimate) such as turning large trees into "the protector" which are prohibited from cutting them, making forests "haunted" so that they do not dare to cut their wood, and determine specific types of wood that are not cut down.

Changes in community attitudes are approached using learning through students who transform during real work lectures or fieldwork lectures. Students are equipped with theories and applications that are ready to be implemented in society as well as 21st-century skills such as critical thinking, communication, collaboration, 
and creativity. Various segments of climate resilience transformation can be done through the green village, blue sky program, green school programs, reducing greenhouse gas emissions, and recycling waste. This program engages the community in their environment as personal capacity building and community transformative practices (Alberta Council for Environmental Education, 2017; Nayan et al., 2020). Programs that involve the government are green growth, green building (National Coordinating Agency for Spatial Planning, 2011). Programs based on community needs and knowledge-based societies (Singh, 2013) can be such as rainwater harvesting or rain harvesting (Drunen, van Lasage, \& Dorland, 2006). Hydro meteorological disaster risk maps can also help the area that is exposed and determine the factors that influence it spatially.

\section{Suggestions}

Climate resilience education really needs to be done in universities in Indonesia so that students can transform educational outcomes in society. The position of climate resilience education can be included in meteorology-climatology or hydrometeorology courses. The life-based curriculum at the Universitas Negeri Malang provides space for the implementation of climate resilience education in the context of life in society. Knowledge of climate, climate change, extreme weather, and its impacts is expected by students to be able to solve problems in society. The climate resilience education model can apply experiential learning models such as problem-based learning, project-based learning, and discovery-inquiry learning.

\section{References}

Alberta Council for Environmental Education (2017). What is Excellent Climate Change Education?

Andrade, H., \& Vieira, R. (2007). A climatic study of an urban green space: The Gulbenkian Park in Lisbon (Portugal). Finisterra, 42(84), 27-46.

Ariansyah, A. (2020). Di Tengah Pandemik COVID - 19, Bencana Hidrometeorologi Dominan Hingga Pekan Kedua April 2020 (Amid the Pandemic COVID-19, Dominant Hydrometeorological Disasters until the Second Week of April 2020). BNPB. https://bnpb.go.id/berita/di-tengah-pandemik-covid-19-bencanahidrometeorologi-dominan-hingga-pekan-kedua-april-2020

Below, T., Artner, A., Siebert, R., \& Sieber, S. (2010). Micro-level practices to adapt to climate change for African small-scale farmers. A Review of Selected Literature, 953.

Bey, G., \& Allen, M. (2019). NOAA Environmental Literacy Program 2019 Resilience Education Grantee Workshop.

Bloomer, E., Landeg, O., \& le Polain de Waroux, O. (2019). Floods as Human Health Risks. In J. Nriagu (Ed.), Encyclopedia of Environmental Health (Second Edition) (pp. 8-18). Elsevier. https://doi.org/10.1016/B978-0-12-409548-9.11462-9

Boer, R., \& Kartikasari, K. (2007). Assessment of Capacity and Needs to Address Vulnerabilities, Adaptations and Resilience to Climate Risks in Indonesia. Bogor: Laboratory of Climatology IPB, April, 1-13.

Bozkurt, F. (2019). Evaluation of Geography Textbooks in Terms of Misconceptions about Climate Topic. Review of International Geographical Education Online, 9(1), 149-170. https://doi.org/10.33403/rigeo.573480 
Bush, D., Sieber, R., Chandler, M. A., \& Sohl, L. E. (2019). Teaching anthropogenic global climate change (AGCC) using climate models. Journal of Geography in Higher Education, 43(4), 527-543.

Chang, C. H., \& Pascua, L. (2015, April 13). Geographical Thinking and its Role in Climate Change Education: A case of Singapore. The Power of Geographical Thinking. IOE Geography Education Conference, London.

Direktorat Pembinaan Sekolah Menengah Atas (Directorate of High School Development). (2017). Panduan Implementasi Kecakapan Abad 21 Kurikulum 2013 di SMA (Guidelines for the Implementation of 21st- Century Skills in 2013 Curriculum in High School). Directorate of High School Development.

DPR Aceh and Gubernur (People's Representative Council of Aceh and Governor). (2019). Qanun Aceh Tentang Pendidikan kebencanaan (The Qanun of Aceh about Disaster Education).

Drunen, M. A. van, Lasage, R., \& Dorland, C. (2006). Climate change in developing countries. CABI publishers. https://research.vu.nl/en/publications/climate-change-indeveloping-countries

Gengaje, R., \& Farquhar, A. (2013). Musim Hujan Akhirnya Hampir Selesai (The Rainy Season Finally Is Almost Over). Buletin Kemanusiaan Bulanan, 1-8.

Georgi, N. J., \& Zafiriadis, K. (2006). The impact of park trees on microclimate in urban areas. Urban Ecosystems, 9(3), 195-209.

Gogtay, N. J., \& Thatte, U. M. (2017). An Introduction to Meta-Analysis. Journal of The Association of Physicians of India, 65, 78-85.

ILO. (n.d.). Organisasi Perburuhan Internasional (International Labor Organization), Investasi Lokal untuk Adaptasi Perubahan Iklim, Green Jobs melalui Pekerjaan Umum Hijau. ILO Office for Indonesia and Timor-Leste.

Kasih, B. T. H., Juaeni, I., \& Harijono, S. W. B. (2007). Proses Meteorologis Bencana Banjir (Flood Disaster Meteorological Process). Jurnal Meteorologi Dan Geofisika, 8(2), 6478.

Katko, T. S., Juuti, P. S., \& Tempelhoff, J. (2010). Water and the city. Environment and History, 16(2), 213-234.

Krasny, M. E., \& Chaopricha, N. T. (2015). Environmental Education and Human Adaptation to Climate Change: Considerations and Resources. Ithaca NY: Cornell University, Civic Ecology Lab.

Kurniawan, H. (2009). Proyeksi Perubahan Iklim Berdasarkan Skenario Ipcc Sres Dengan Menggunakan Model Aogcm Ccsr / Nies (Climate Change Projection Based on the Ipcc Sres Scenario Using the Aogcm Ccsr / Nies Model). Buletin Meteorologi, Klimatologi Dan Geofisika, 5(2), 139-149.

Lane, R. (2015). Primary Geography in Australia: Pre-Service Primary Teachers' Understandings of Weather and Climate. Review of International Geographical Education Online, 5(2), 19.

Lapan. (2007). Pemantauan Banjir di Kabupaten Pesisir Selatan Provinsi Sumatera Barat (Flood Monitoring in the Southern Coastal District of Western Sumatra Province). Pusat Pengembangan Pemanfaatan Dan Teknologi Penginderaan Jauh Lembaga Penerbangan Dan Antariksa Nasional (The Center for Development of Remote Sensing Utilization and Technology of the National Aeronautics and Space Institute). 
Luetz, J. M., Margus, R., \& Prickett, B. (2020). Human Behavior Change for Sustainable Development: Perspectives Informed by Psychology and Neuroscience. Quality Education, 419-434.

Mashur, D., \& Meiwanda, G. (2019). Adaptation and Mitigation of Climate Change Based on Community Empowerment. Jurnal Kebijakan Publik, 10(1), 25-32.

Miola, A., Paccagnan, V., \& Mandrici, A. (2015). Climate Resilient Development Index: Theoretical Framework, Selection Criteria and fit for Purpose Indicators. European Commision. https://doi.org/10.2788/07628

Monroe, M. C., Plate, R. R., Oxarart, A., Bowers, A., \& Chaves, W. A. (2019). Identifying effective climate change education strategies: A systematic review of the research. Environmental Education Research, 25(6), 791-812. https://doi.org/10.1080/ 13504622.2017.1360842

National Coordinating Agency for Spatial Planning. (2011). Perubahan Iklim Bencana Saat ini atau Masa Datang (Climate change Disasters: Current or Future). Buletin Tata Ruang, May-June.

Nayan, N., MohmadiSa, H., HaniFah, M., Yazid, S., \& SyaiDatiNa BalkhiS, N. (2020). Youth Climate Change Mitigation Practices and Adaptation in Malacca State, Malaysia. Review of International Geographical Education Online, 10(2), 58-71. https://doi.org/10.33403/rigeo.545819

Nhan, D. K., Be, N. V., \& Trung, N. H. (2007). Water use and competition in the Mekong Delta, Vietnam. Challenges to Sustainable Development in the Mekong Delta: Regional and National Policy Issues and Research Needs. The Sustainable Mekong Research Network, 143-188.

Paytan, A., Weiss, E., \& Halversen, S. (2017). Climate Change Education for Adaptation and Resilience. Https://Goldschmidt.Info/2017/Index, 71-73.

Piróg, D. (2014). Educating for Hope in Troubled Times: Climate Change and the Transition to a Post-Carbon Future. Review of International Geographical Education Online, 4(3), 281-285.

Prayoga, N., \& Sutarto, R. (2018). Panduan Penyusunan Strategi Ketahanan Kota (Guidance for Developing City Resilience Strategies). Mercy Corps.

Puspijak dan BPTK Pengelolaan DAS Solo (Climate Change Research and Policy Center and Conservation Technology Research Center on Watershed management in Solo). (2013). Mengelola Ketidakpastian Dampak Perubahan Iklim Adaptasi Masyarakat Pesisir (Managing the Uncertain Impacts of Climate Change Adaptation to Coastal Communities). Policy Brief, 7(8), 1-8.

Qodriyatun, S. N. (2013). Bencana Hidrometrologi dan Upaya Adaptasi Perubahan Iklim (Hydrometeorological Disasters and The Effort of Climate Change Adaptation). Info Singkat, 5(10), 9-12.

Reid, A. (2019). Climate change education and research: Possibilities and potentials versus problems and perils? Taylor \& Francis.

Schrot, O. G., Keller, L., Peduzzi, D., Riede, M., Kuthe, A., \& Ludwig, D. (2019). Teenagers Expand Their Conceptions of Climate Change Adaptation Through ResearchEducation Cooperation. In W. Leal Filho \& S. L. Hemstock (Eds.), Climate Change and the Role of Education (pp. 525-547). Springer International Publishing. https://doi.org/10.1007/978-3-030-32898-6_29 
Seroussi, D.-E., Rothschild, N., Kurzbaum, E., Yaffe, Y., \& Hemo, T. (2019). Teachers' Knowledge, Beliefs, and Attitudes about Climate Change. International Education Studies, 12(8), p33. https://doi.org/10.5539/ies.v12n8p33

Singh, J. (2013). Role of Education in Knowledge Based Society. In Recommendations of National Knowledge Commission: Directions for Implementation (1st ed., pp. 29-34). Council for Teacher Education.

Steinbach, D., Kaur, N., Manuel, C., \& Saigal, S. (2017). Building resilience to climate change: MGNREGS, drought and flooding in Odisha.

Sumarmi, S., Bachri, S., Irawan, L. Y., Putra, D. B. P., Risnani, R., \& Aliman, M. (2020). The Effect of Experiential Learning Models on High School Students Learning Scores and Disaster Countermeasures Education Abilities. Journal for the Education of Gifted Young Scientists, 8(1), 61-85. https://doi.org/10.17478/jegys.635632

Taylor, J. (2013). Kajian Kerentanan Perubahan Iklim Kota Makassar (Makassar City Climate Change Vulnerability Study). United Nations Environment Programme (UNEP).

The World Bank Groups. (2019). Action Plan on Climate Change Adaptation and Resilience, Managing Risks for a More Resilient Future. The World Bank Groups.

Tong, S., \& Ebi, K. (2019). Preventing and mitigating health risks of climate change. Environmental Research.

Undang-Undang Republik Indonesia Nomor 16 (The Law of the Republic of Indonesia Number 16). (2016). Pengesahan Paris Agreement to the United Nations Framework Convention on Climate Change (Ratification of the Paris Agreement to the United Nations Framework Convention on Climate Change).

UNDP Indonesia. (2007). Sisi Lain Perubahan Iklim (The Other Side of Climate Change).

UNESCO. (2012). Climate Change. UNESCO.

Viero, D. P., Roder, G., Matticchio, B., Defina, A., \& Tarolli, P. (2019). Floods, landscape modifications and population dynamics in anthropogenic coastal lowlands: The Polesine (northern Italy) case study. Science of The Total Environment, 651, 14351450 .

Zubaidah, S. (2016). Keterampilan Abad ke-21: Keterampilan yang diajarkan melalui Pembelajaran (The 21st-Century Skills: Skills that Taught Through Learning). Seminar Nasional Pendidikan Dengan Tema "Isu-Isu Strategis Pembelajaran MIPA Abad, 21(10), 1-17.

\section{Biographical Statements}

Dwiyono Hari UTOMO is an Associate Professor, Doctor at the Department of Geography Education, Faculty of Social Science at the Universitas Negeri Malang. He teaches meteorology-climatology, soil geography, and teaching material development. id scopus: 57208468525 .

Muhammad ALIMAN is the research assistant in Geography Education Department, Social Science Faculty of State University of Malang. Expert in geography education. Scopus ID: 57210109291. 